This item was submitted to Loughborough's Research Repository by the author.

Items in Figshare are protected by copyright, with all rights reserved, unless otherwise indicated.

\title{
Short- and long-run decompositions of UK wage inequality changes
}

PLEASE CITE THE PUBLISHED VERSION

PUBLISHER

(C) Blackwell

VERSION

AM (Accepted Manuscript)

LICENCE

CC BY-NC-ND 4.0

REPOSITORY RECORD

Edwards, T. Huw, and John Whalley. 2019. "Short- and Long-run Decompositions of UK Wage Inequality Changes”. figshare. https://hdl.handle.net/2134/2737. 
This item was submitted to Loughborough's Institutional Repository by the author and is made available under the following Creative Commons Licence conditions.

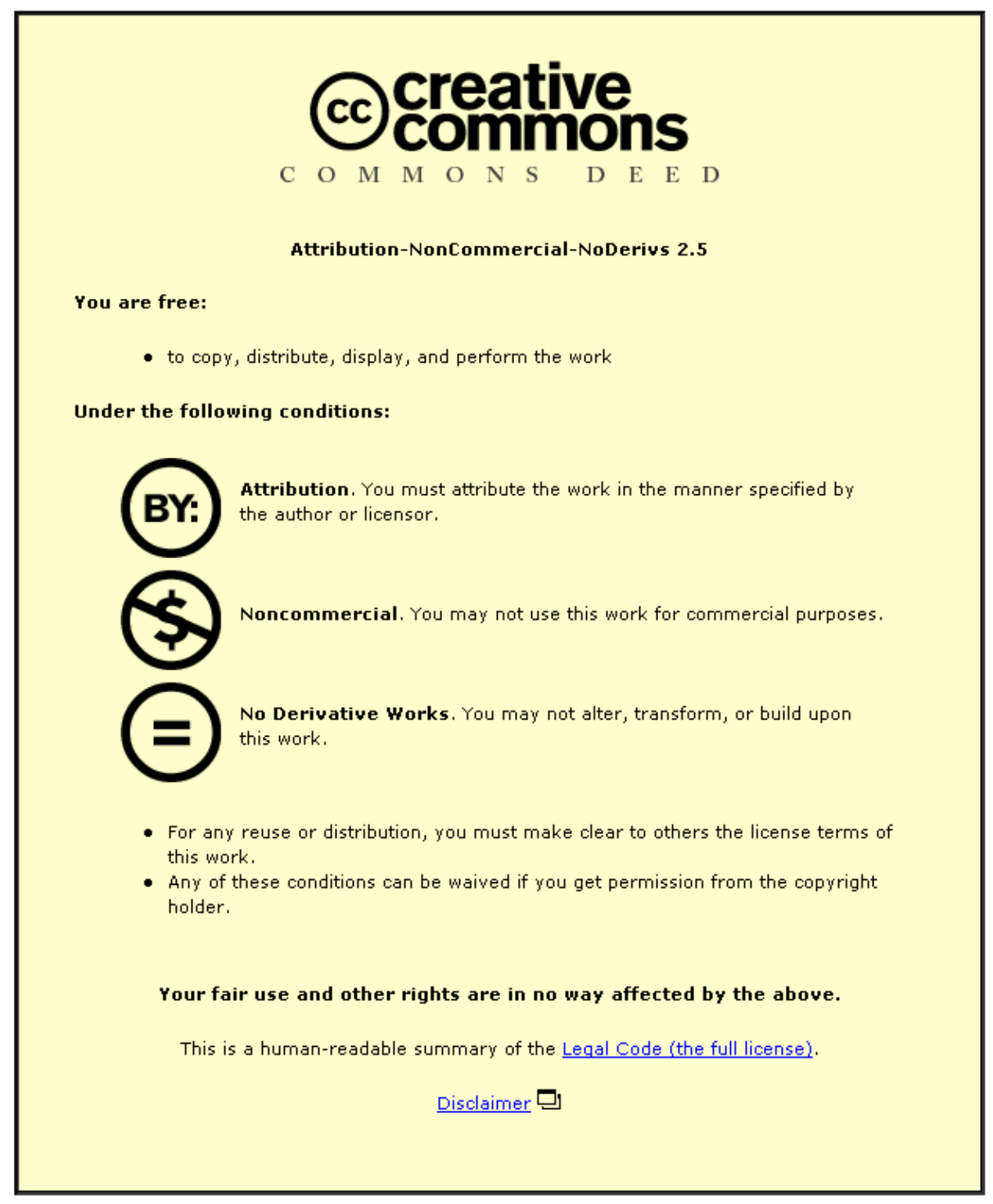

For the full text of this licence, please go to: http://creativecommons.org/licenses/by-nc-nd/2.5/ 


\title{
SHORT- AND LONG-RUN
}

\section{DECOMPOSITIONS OF UK WAGE}

\author{
INEQUALITY CHANGES*
}

\author{
T. Huw Edwards \\ Loughborough University and CSGR Warwick, UK.
}

John Whalley

University of Western Ontario, and NBER

\begin{abstract}
This paper focuses on the decomposition of observed increases in UK wage inequality since 1979 into the component factors of competition from low-wage imports and technological change. Building on recent work by Abrego and Whalley, it argues that the length of production run and degree of fixity of factors is crucial in such analyses. If the response of labour markets to date is a short-run response, in which factors and output have not adjusted fully, then analysis of the causes of increased inequality is substantially altered relative to a long-run factors mobile world.

KEYWORDS: Trade, inequality, technology, general equilibrium.

JEL classification: F16, J31, C68.

*This paper forms part of a project on Globalisation and Social Exclusion supported by the EU, executed at the University of Warwick. We are grateful to Lisandro Abrego, Carlo Perroni, Paul Brenton, Matthias Lücke, Ana Rutte Cardoso, Ray Riezman, David Collie, Geoff Reed and Ben Zissimos for conversations and suggestions, as well as to two anonymous
\end{abstract} referees. 


\section{INTRODUCTION}

This paper focuses on the causes of increased wage inequality in OECD countries in recent years, more specifically its decomposition into the component factors of trade surges in low wage products and technological change that has preoccupied the trade and wages literature. ${ }^{1}$ We argue that if we assume that the observed wage inequality response to price and technology shocks reflects a short-run response in which factor allocations and output have not fully adjusted across industries, then decomposition analysis of the causes of the observed increases in inequality is substantially altered relative to a long-run world in which all factors are mobile. This finding is important because most data used in the debate are interpreted as reflective of a long-run full mobility response, when this may not be the case. Incorrect conclusions as to how trade surges and technology contribute to wage inequality can be easily drawn if analysis based upon a long-run model is applied to data generated by a short-run adjustment process.

We examine two cases of factor immobility: a two-factor model where one factor is subject to mobility costs, and a model with sector-specific capital, in the spirit of Ricardo-Viner. In both cases, relatively small departures from the fully mobile Hecksher-Ohlin model noticeably change the decomposition results.

\section{TRADE, TECHNICAL PROGRESS AND DECOMPOSING WAGE INEQUALITY CHANGES}

The trade and wages debate is a response to the observed increase in wage

\footnotetext{
${ }^{1}$ See Wood (1994), Haskel and Slaughter (1998), Slaughter (1999) and Leamer (1998).
} 
inequality in the Anglo-Saxon economies since the late 1970s, and the possibly associated rise in long-term unemployment in Continental European economies where labour markets are seen as less flexible. The consequence has been a backlash in many Western economies against the perceived threat to unskilled workers' jobs from imports of low-skilled goods from Asian and other developing economies, summarised by Freeman (1995) in a provocatively-titled review article: 'Are your wages set in Beijing'. His conclusion - in line with most studies was one of guarded scepticism. However, Leamer (1996) argues that the widening U.S. wage inequality in the 1980s may reflect a delayed Stolper-Samuelsonstyle response to a fall in low-skill manufactures prices in the 1970 s. $^{2}$ The most frequent alternative mentioned in the literature is that the primary reason for declining demand for unskilled labour is factor-biased technical change, in the form of skill-upgrading within industries. ${ }^{3}$ A third explanation - sector-biased technical progress - is that technical progress within advanced countries, in the form of computerization, has been concentrated in higher-skill industries, increasing their competitiveness and causing a switch in advanced countries' trade specialization. ${ }^{4}$

Decomposition of the observed inequality changes therefore needs to take account of factor- and sector- bias in technical progress, as well as changing relative global commodity prices and a variety of other factors, such as changing relative supplies of skilled and unskilled labour (which may partly reflect

\footnotetext{
${ }^{2}$ Wood (1994) also points the finger at low-wage competition from abroad.

${ }^{3}$ See Bound and Johnson (1992), Berman et al. (1994), Berman et al. (1998).

${ }^{4}$ See Haskel and Slaughter (2002).
} 
migration: see, e.g. Borjas et al. (1992)). However, such decomposition analysis - and hence the confidence with which we can determine whether 'trade' or 'technology' is the primary cause of increasing inequality - is likely to be sensitive to assumptions about the underlying trade model (see Abrego and Whalley (1999a, 1990b and 2000)). Our paper is a response to these concerns, in particular to the specific issue of factor fixity. By comparing a range of decompositions across a variety of different factor fixity assumptions, which, in turn, are related to the question of whether we are assuming a short-run or a long-run response, we illustrate the lack of robustness of existing wage inequality decompositions, and how important it is to acquire additional information to make assessment more reliable. In addition, the paper casts some new light on the argument of whether the Stolper-Samuelson-related mandated wages approach to decomposition is necessarily more reliable than the more traditional factor contents approach. $^{5}$

\section{LONG AND SHORT RUN MODELS FOR TRADE AND}

\section{WAGES ANALYSIS}

We use trade-based models to decompose the observed change in skilledunskilled wage inequality in the UK between 1979 and 1995 to evaluate the relative importance of world prices (trade changes) and technological progress (whether sector- or factor-biased) in generating wage change. We compare results from short-run models in which some factors are either immobile or face adjustment costs moving between sectors, to those from a longer-run Heckscher-

\footnotetext{
${ }^{5}$ For the debate on the validity of the factor contents approach, see Deardorff and Staiger (1988), Leamer (2000) and Deardorff (2000).
} 
Ohlin type model where all factors are fully mobile between industries.

Models where not all factors can move easily between sectors (Mayer (1974), Mussa (1974) and Neary (1978)) have been used to investigate the implications of this feature for relative incomes in a two-factor model (such as whether the Stolper-Samuleson theorem still holds) and are the starting point for this paper. In these papers, the factor inputs are labour and capital, with capital immobile between sectors. ${ }^{6}$

We discuss the case where the factor inputs are unskilled $(U)$ and skilled $(S)$ labour, with $U$ being the factor subject to adjustment costs. In this case, if there is a fall in the world price of the $U$-intensive good, with $S$ freely mobile between sectors, then since $U$ cannot easily move towards the $S$-intensive sector in the short run, its wage will rise in the expanding sector and fall more steeply than the goods price in the declining sector. The wage of $S$ will fall in the short run, though by less than the fall in the price of the $U$-intensive good. In the longer run, as factor $U$ becomes free to move towards the $S$-intensive sector where its wage is higher, the output of this sector will expand. Given the shift towards the $S$-intensive sector, $S$ 's wages will rise, while $U$ 's wage will fall further in both sectors. This relative wage effect reflecting the shift over time in factors can be more marked than the initial impact effect of the price shock, and is the main factor behind the long-run Stolper-Samuelson influences on relative wages (a fall in the $U$-intensive good price will reduce $U$ 's wage and raise $S$ 's wage).

Although $U$ 's income will fall sharply in the $U$-intensive sector when the

\footnotetext{
${ }^{6}$ Note that, in this case, capital in each sector is effectively a separate factor, so this is often described as a three-factor model.
} 
goods price falls, it will actually fall further, rather than be mitigated, once $U$ becomes free to move to the other sector, as $S$ 's share of income gets bid up by the shift of output to the $S$-intensive sector. This suggests that some of the conclusions of the short-run model may differ from those predicted by the longerrun $\mathrm{H}-\mathrm{O}$ model, in that much of the impact of trade on relative factor rewards (the 'magnification' effect ${ }^{7}$ ) requires factor rewards to be equated across sectors (which, in turn, will lead to changes in output): something which requires factor movement except in the polar case of Leontief production technologies. Also factor price insensitivity to endowments does not apply when not all factors are able to move, so any 'short-run' study of the causes of changing wage inequality needs to take account of changing endowments, not simply world prices and technology.

This conclusion is supported by our alternative, specific factor case, where both types of labour are mobile, but capital is immobile. Again, the capital immobility reduces the shift in output between sectors in response to a price change, with the effects depending, among other things, on relative factor intensities. On the simulations carried out for the UK, this has a damping effect on changes in labour demand and wages, which becomes significant even with relatively small amounts of the fixed factor present. Sector output movement and changes in factor demand are noticeably reduced even when only $2 \%$ to $5 \%$

\footnotetext{
${ }^{7}$ Jones (1965) identified the 'magnification' effect of product prices on factor prices, whereby if the price of a labour-intensive good (say good $L$ ) rises relative to a capital-intensive good $(K)$, the effect upon relative factor rewards is greater than the change in relative goods prices, so that, if initial prices are $1, w>P_{L}>P_{K}>r$. This result assumes the market equates factor rewards across sectors.
} 
of value added comprises a fixed factor.

We consider the possibility that the changes in relative wages observed in a small open economy reflect the short-run response of the economy to a combination of world price, technological and demographic shocks. The procedures we employ are to calibrate a numerical general equilibrium model to the UK economy using data for 1979 and 1995, and then to make computations to decompose the observed change into component parts by considering the effects of changes separately. We use a Heckscher-Ohlin model, which assumes that factors can freely move between sectors, a short-term model which incorporates adjustment costs for unskilled labour and a model with a sector-specific factor.

\subsection{A Long-run Trade and Wages Model}

For our long-run model, we use a 2-factor, 2-sector Heckscher-Ohlin type formulation of a small, open economy. ${ }^{8}$ Of the two sectors, sector $E$ (exportables) is assumed to be intensive in the use of skilled factor $S$ relative to sector $M$ (importables): i.e. $U_{E} / S_{E}<U_{M} / S_{M}$. This holds for any pair of wage rates $W_{u}$ and $W_{s}$ (ie there are no factor intensity reversals). The factor input-output ratios for $E$ and $M$, which we denote $a u_{E}, a s_{E}, a u_{M}$ and $a s_{M}$, are all functions of $W_{u}$ and $W_{s}$.

We assume both labour markets are perfectly competitive. In equilibrium, these markets will clear, and factor prices and the associated input-output ratios

\footnotetext{
${ }^{8}$ Strictly speaking, Heckscher-Ohlin trade models provide an explanation of trade patterns between countries in terms of relative factor abundance. We use the term here to refer to a mobile factors formulation of a single country.
} 
will all adjust to clear the two factor markets. These equilibrium conditions imply that

$$
\begin{aligned}
& a u_{E}\left\{W_{u}, W_{s}\right\} Y_{E}+a u_{M}\left\{W_{u}, W_{s}\right\} Y_{M}=\bar{U} \\
& a s_{E}\left\{W_{u}, W_{s}\right\} Y_{E}+a s_{M}\left\{W_{u}, W_{s}\right\} Y_{M}=\bar{S}
\end{aligned}
$$

where $Y_{E}$ and $Y_{M}$ are outputs of the two goods and $\bar{U}$ and $\bar{S}$ are the economywide endowments of unskilled and skilled labour.

Competition ensures prices equal unit costs in both sectors, i.e.

$$
\begin{gathered}
a u_{E}\left\{W_{u}, W_{s}\right\} W_{U}+a s_{E}\left\{W_{u}, W_{s}\right\} W_{S}=\bar{P}_{E} ; \\
a u_{M}\left\{W_{u}, W_{s}\right\} W_{U}+a s_{M}\left\{W_{u}, W_{s}\right\} W_{S}=\bar{P}_{M} ;
\end{gathered}
$$

where $\bar{P}_{E}$ and $\bar{P}_{M}$ are the two goods prices set on the world market.

In order to capture the separate effects of factor- and sector-biased technical progress, we use a CES production function for each sector of the form

$$
Y_{i}=A_{i}\left[\beta_{i}\left(\alpha_{u} U_{i}\right)^{\left(\left(\sigma_{i}-1\right) / \sigma_{i}\right)}+\left(1-\beta_{i}\right)\left(\alpha_{s} S_{i}\right)^{\left(\left(\sigma_{i}-1\right) / \sigma_{i}\right)}\right]^{\left(\sigma_{i} /\left(\sigma_{i}-1\right)\right)},
$$

where $A_{i}$ is a scale parameter, $\sigma_{i}$ is the elasticity of substitution between skilled and unskilled labour in production, $\beta_{i}$ is a share parameter and $\alpha_{u}$ and $\alpha_{s}$ are factor-augmenting parameters. We can interpret an increase in $A_{i}$ as representing a general increase in total factor productivity in sector $i$, which is purely sector-biased in its effects. Changes in $\alpha_{u}$ and $\alpha_{s}$ represent technical progress 
which increases the productivity of one factor across both sectors (factor-biased technological change), or, alternatively, changes in factor quality over time. Henceforth, we assume $\alpha_{u}$ and $\alpha_{s}$ are the same across sectors: the different factor shares in output between the sectors are determined by the $\beta_{i}$ parameters.

For simplicity, we assume the elasticity of substitution between factors, $\sigma_{i}$, is the same in both sectors. We can therefore amend (3) to read:

$$
Y_{i}=A_{i}\left[\beta_{i}\left(\alpha_{u} U_{i}\right)^{(\sigma-1) / \sigma)}+\left(1-\beta_{i}\right)\left(\alpha_{s} S_{i}\right)^{((\sigma-1) / \sigma)}\right]^{(\sigma /(\sigma-1))} .
$$

In the calibrations and simulations summarised below, a central case value is assumed for the elasticity of substitution, $\sigma=1.25$, with sensitivity cases of 0.5 and 2 .

In a perfectly competitive industry, relative factor rewards will be equated to the value of marginal product. Consequently, for any level of output $Y_{i}, W_{u}$ and $W_{s}$ can be derived by differentiating (3) with respect to $U_{i}$ and $S_{i}$ respectively, setting the marginal products of $U_{i}$ and $S_{i}$ equal to the respective wages divided by the product price, and then rearranging. Hence we derive

$$
\begin{aligned}
& W_{u}=P_{i} A_{i}\left(Y_{i} / A_{i} U_{i}\right)^{1 / \sigma} \beta_{i}\left(\alpha_{u}\right)^{(\sigma-1) / \sigma}, \\
& W_{s}=P_{i} A_{i}\left(Y_{i} / A_{i} S_{i}\right)^{1 / \sigma}\left(1-\beta_{i}\right)\left(\alpha_{s}\right)^{(\sigma-1) / \sigma} .
\end{aligned}
$$

Alternatively, we can rearrange (4) to derive $\left(U_{i} / Y_{i}\right)$ and $\left(S_{i} / Y_{i}\right)$ :

$$
U_{i} / Y_{i}=A_{i}^{\sigma-1}\left(W_{u} /\left(\beta_{i} P_{i}\right)\right)^{-\sigma} \alpha_{u}^{\sigma-1},
$$




$$
S_{i} / Y_{i}=A_{i}^{\sigma-1}\left(W_{s} /\left(\left(1-\beta_{i}\right) P_{i}\right)\right)^{-\sigma} \alpha_{s}^{\sigma-1}
$$

Noting that the zero profit conditions for each sector imply $P_{i}=W_{u}\left(U_{i} / Y_{i}\right)+$ $W_{s}\left(S_{i} / Y_{i}\right)$, we can substitute in for $\left(U_{i} / Y_{i}\right)$ and $\left(S_{i} / Y_{i}\right)$ to obtain prices for the two sectors, which are equated by competition to unit costs,

$$
P_{i}=A_{i}^{-1}\left\{W_{u}^{\sigma-1} \beta_{i}^{\sigma} \alpha_{u}^{\sigma-1}+W_{s}^{1-\sigma}\left(1-\beta_{i}\right)^{\sigma} \alpha_{s}^{\sigma-1}\right\}^{1 /(1-\sigma)} .
$$

Defining

$$
\begin{aligned}
\theta_{s i} & =\left(1-\beta_{i}\right)^{\sigma} / \alpha_{s}^{1-\sigma}, \\
\theta_{u i} & =\beta_{i}{ }^{\sigma} / \alpha_{u}^{1-\sigma}, \\
i & =\{E, M\},
\end{aligned}
$$

we can write

$$
P_{i}^{1-\sigma} A_{i}^{1-\sigma}=\theta_{u i} W_{u}^{1-\sigma}+\theta_{s i} W_{s}^{1-\sigma}
$$

and cross-multiplying these equations for industries $E$ and $M$ gives us:

$$
\begin{aligned}
\left(P_{E} A_{E}\right)^{1-\sigma}\left(\theta_{U M} W_{u}^{1-\sigma}+\theta_{S M} W_{s}^{1-\sigma}\right) & =\left(P_{M} A_{M}\right)^{1-\sigma}\left(\theta_{U E} W_{u}^{1-\sigma}+\theta_{S E} W_{s}^{1-\sigma}\right) ; \quad(7) \\
W_{u}^{1-\sigma}\left[\left(P_{E} A_{E}\right)^{1-\sigma} \theta_{U M}-\left(P_{M} A_{M}\right)^{1-\sigma} \theta_{U E}\right] & =W_{s}^{1-\sigma}\left[\left(P_{M} A_{M}\right)^{1-\sigma} \theta_{S E}-\left(P_{E} A_{E}\right)^{1-\sigma} \theta_{S M}\right] .
\end{aligned}
$$

Hence we can derive the ratio $W_{S} / W_{U}$. 
$W_{s} / W_{u}=\left\{\left[\theta_{u m}\left(P_{E} A_{E} / P_{M} A_{M}\right)^{1-\sigma}-\theta_{u E}\right] /\left[\theta_{S E}-\theta_{S M}\left(P_{E} A_{E} / P_{M} A_{M}\right)^{1-\sigma}\right]\right\}^{1 / 1-\sigma}$.

In this formulation, $W_{s} / W_{u}$ is higher the larger is $P_{E}$ or $A_{E}$, and the smaller is $P_{M}$ or $A_{M}$. An increase in $\alpha_{u} / \alpha_{s}$ will reduce $W_{s} / W_{u}$ (this is the same result as in Davis (1997) and Haskel and Slaughter (2002)). Changes in the CES share parameters, $\beta$, however, have ambiguous effects on relative wages.

As Abrego and Whalley (2000) note, following Harry Johnson (1966), in the CES case specialization can occur for relatively small changes in goods prices (depending upon relative factor intensities and the elasticity of substitution). ${ }^{9}$ If specialization does occur, beyond this point traded goods prices do not affect relative wages, though changes in factor supplies will have an influence.

It is worth noting that the model equations outlined above do not contain any statement of consumer demand or utility. In this framework, prices of all goods are set on the world markets, and consumer demand at home does not affect prices or output if we assume the economy is small and open. This means that the production and consumption sides of the economy are separable; and given our focus on the determination of relative wage change we can concentrate on modelling the production side alone. The same argument applies for the short run model to which we turn next.

${ }^{9}$ This result is, however, very sensitive to the elasticity of substitution - see Melvin (1971). 


\subsection{A Short-run Adjustment Model of Trade and Wages}

We formulate a short-run trade and wages model similar to the long-run model above, but in which labour cannot move costlessly between sectors due to adjustment costs. These may be search costs, transportation or removal costs, transactions costs in housing markets, or even psychological costs and preference for location.

In the model, we assume these transactions costs create a wedge between the wage offered in the sector where labour is currently employed and the wage needed to be offered in another sector in order for a worker to move. Wage rates in sectors which are expanding following an international price shock to the economy are thus higher than those in contracting sectors where labour shedding occurs.

We start out by looking at the theoretical properties of this model. In this model, factor $U$ will only move from a declining sector $M$ to an expanding sector $E$ if wages in $E$ exceed those in $M$ by some proportionate amount $\lambda_{u i}$ : ie if $W_{u E}-W_{u M} \geq \lambda_{u} W_{u M}$, and likewise for factor $S$ if it also faces adjustment costs. This means that a sector can, in principle, fall into one of three potential categories: (i) it can be an expanding sector, where employers pay a high wage (gross of adjustment cost), (ii) it can be a declining sector, where the wage is lower, but adjustment costs are lower or (iii) it can be a static sector. In this latter case, the sector concerned will pay wages high enough that its labour force does not find it attractive to move to another sector once adjustment costs are 
taken into account, but not so high that it attracts labour from the other sector.

In expanding sectors (denoted sector $i$, a member of set $e$ of all expanding sectors), we define the wage gross of adjustment costs as $W_{u e}^{g}$. The wage net of adjustment costs is then $W_{u e}^{n}=W_{u e}^{g} /\left(1+\lambda_{U}\right)$. In declining sectors $(i$ is a member of set $d$, the set of declining sectors) the wage rate $W_{u d}$ will be the same as the wage in expanding sectors $W_{u e}$ net of adjustment costs, which in turn equals $W_{u e}^{g} /\left(1+\lambda_{U}\right)$. Potentially, there may also be some sectors whose output may fetch a declining price, but where workers will take a lower wage rather than become unemployed: these will have unchanged employment if the wage lies between $W_{u e}^{g}$ and $W_{u e}^{g} /\left(1+\lambda_{U}\right)$.

To capture these features we modify equation (4) to apply different wages to different sectors, expressing wages in all sectors in relation to the gross wage in the expanding sectors, $W_{u e}^{g}$. We will call this our reference wage, and label it as $W_{u}^{R}$. As we consider a two sector model, there are, in theory, two possible outcomes - first, one sector may be expanding and the other contracting, or alternatively both sectors may be static, but with one, advantaged sector paying a higher wage than the other, disadvantaged sector. In practice, we do not observe a situation where both sectors are static, but we consider its properties here for the sake of completeness.

For each sector, we express the proportional difference between the wage received by labour in the unskilled intensive sector $W_{u}^{R}$, and the (gross of adjustment cost) wage paid by employers, $W_{u}^{g}$ as $l u_{i}$. This allows us to characterise the difference in sectoral wage rates as follows: 


$$
\begin{aligned}
& \text { In expanding sectors }(i \subset e): l u_{i}=0 \text {; } \\
& \text { In declining sectors }(i \subset d): l u_{i}=\lambda_{u} \text {; }
\end{aligned}
$$

In other words, the wage discount cannot exceed $\lambda_{u}$, since otherwise labour would move, reducing the discount back to this level.

We define the benchmark (pre-shock) levels of employment of $U$ and $S$ in each sector as $U_{i}^{*}$ and $S_{i}^{*}$; the levels of employment if nobody leaves the sector. In a declining sector $i(i \subset d$,$) adjustment costs mean that the wage discount$ factor $l u_{i}$ equals the maximum permitted, $\lambda_{u}$, and labour can move (ie the sector is 'declining').

The adjustment costs borne by those factors which move (which may be in the form of either temporary unemployment or a loss of productive efficiency) are given by:

$$
\begin{aligned}
& \mu_{u}=W_{u}^{R} \sum_{i} l u_{i}\left(U_{i}^{*}-U_{i}\right) \\
& \mu_{s}=W_{s}^{R} \sum_{i} l s_{i}\left(S_{i}^{*}-S_{i}\right) .
\end{aligned}
$$

If adjustment costs are denominated in units of labour, this reduces effective 
economy-wide endowments

$$
\begin{aligned}
\sum_{i} U_{i} & =\bar{U}-\mu_{u i} / W_{u}^{R} \\
\sum_{i} S_{i} & =\bar{S}-\mu_{s i} / W_{s}^{R} .
\end{aligned}
$$

The effects of introducing adjustment costs into the model are thus: i) the wage of each factor will now differ between sectors by a proportion $\lambda_{u}$ for $U$ and $\lambda_{s}$ for $S$. (ii) Factors are now less mobile in response to a price or other shock. In particular, there is a range of traded goods prices over which factors will not move, and this is wider the larger are $\lambda_{u}$ and $\lambda_{s}$. (iii) Following Neary (1998) reduced mobility reduces the effects of product price changes on relative wage changes in both sectors. (iv) Because of the effects of the adjustment costs on factor movements and relative wages, the specialization effects in a classical Heckscher-Ohlin model are less likely to occur. The modified model is easier to reconcile with observed data, where extreme changes to specialisation are not observed. (v) If we assume that in the long run $\lambda_{u}$ and $\lambda_{s}$ are zero, a price change will have larger effects on output, employment and wages in the long run than over the short-run. (vi) the long-run model is simply the short-run model with the parameters $\lambda_{u}$ and $\lambda_{s}$ set to zero.

\subsection{A Fixed Factor Model of Trade and Wages}

Our specific factor model utilises a nested CES function to combine three factors: unskilled labour, $U$, skilled labour, $S$, and capital. Skilled and unskilled labour are mobile across sectors with a common wage, $W_{s}$ or $W_{u}$ respectively, 
while capital is sector specific, set at a level $K_{i}$. A CES nesting structure is used in which the two types of labour are used in each sector $i$ are combined to form aggregate labour $L_{i}$ using a CES aggregation. This is then combined with capital in a Cobb-Douglas function to yield total sectoral output, $Y_{i} \cdot{ }^{10}$

The CES aggregation function for the sectoral labour aggregate, $L_{i}$, is of the same form as equation (3)

$$
L_{i}=A_{i}\left[\beta_{i}\left(\alpha_{u} U_{i}\right)^{(\sigma-1) / \sigma}+\left(1-\beta_{i}\right)\left(\alpha_{s} S_{i}\right)^{(\sigma-1) / \sigma}\right]^{\sigma /(\sigma-1)} \quad ;(i=u, s) .
$$

If we define an aggregate labour wage, $W_{i}$, as an average of skilled and unskilled wages for each sector, then the first order conditions for employment of each type of labour in a competitive market can be written as $d L_{i} / d U_{i}=W_{u} / W_{i}$ and $d L_{i} / d S_{i}=W_{s} / W_{i}$. We can obtain $d L_{i} / d U_{i}$ and $d L_{i} / d S_{i}$ by differentiating (12). Consequently we can rearrange this to express the two wages $W_{u}$ and $W_{s}$ in terms of $W_{i}, L_{i}, U_{i}$ and $S_{i}$ :

$$
\begin{aligned}
& W_{u}=W_{i} A_{i}\left(L_{i} / A_{i} U_{i}\right)^{1 / \sigma} \beta_{i} \alpha_{u}^{\sigma /(\sigma-1)}, \quad(i=u, s), \\
& W_{s}=W_{i} A_{i}\left(L_{i} / A_{i} S_{i}\right)^{1 / \sigma}\left(1-\beta_{i}\right) \alpha_{u}^{\sigma /(\sigma-1)}, \quad(i=u, s),
\end{aligned}
$$

which implies that

$$
U_{i} / L_{i}=A_{i}^{\sigma-1}\left(W_{u} /\left(\beta_{i} W_{i}\right)\right)^{-\sigma} \alpha_{u}^{\sigma-1}
$$

\footnotetext{
${ }^{10}$ Strictly speaking, this model is not just an extension to the other two models, although it is probably as close to them as can be achieved given the number of factors has been altered.
} 


$$
S_{i} / L_{i}=A_{i}^{\sigma-1}\left(W_{s} /\left(\left(1-\beta_{i}\right) W_{i}\right)\right)^{-\sigma_{i}} \alpha_{s}^{\sigma_{i}-1},
$$

or

$$
S_{i} / U_{i}=\left(W_{s} / W_{u}\right)^{-\sigma_{i}}\left(\left(1-\beta_{i}\right) / \beta i\right)^{-\sigma_{i}}\left(\alpha_{u} / \alpha_{s}\right)^{\left(1-\sigma_{i}\right)} .
$$

The aggregate labour wage, $W_{i}$ can be normalised to equal the average of skilled and unskilled wages in the sector :

$$
W_{i}=\left(W_{u} U_{i}+W_{s} S_{i}\right) / L_{i} .
$$

The Cobb-Douglas aggregation of $L_{i}$ and $K_{i}$ to form $Y_{i}$ is given by: $Y_{i}=$ $\Upsilon_{i} K_{i}^{\gamma_{i}} L_{i}^{1-\gamma_{i}}$, where $0<\gamma_{i}<1$.

$\gamma_{i}$ is the capital share coefficient for industry $I, \Upsilon_{i}$ is a scale coefficient and from the first order conditions

$$
\begin{aligned}
L_{i} & =\left(1-\gamma_{i}\right) P_{i} Y_{i} / W_{i}, \\
R_{i} & =\gamma_{i} P_{i} Y_{i},
\end{aligned}
$$

where $R_{i}$ is the rental return to capital. 


\section{CALIBRATION AND DATA}

To use these models in decomposition experiments to assess the relative importance of trade surges and technological change for changes in wage inequality, we calibrate each to observed data for 1979 and 1995 for the UK. Since our aim is to compare the effects of different trade model structures upon decomposition, and since one of the central structures which we wish to investigate is the Heckscher-Ohlin framework, our starting-point has to be compatible with this theory. The Heckscher-Ohlin model has a series of strong implied properties, notably that a small, open economy cannot produce a greater number of goods than it has factor types - indeed, for the Stolper-Samuelson theorem to hold, it has to produce the same number of goods as it has factors both before and after a trade shock. Consequently, if we are modelling the effects of trade on returns to just two, sectorally mobile factors (skilled and unskilled labour), then we need to calibrate our model to a very simplified, schematic model with just two sectors in production (skilled- and unskilled-intensive). For this purpose, we aggregate together the sectors in official statistics into two broad sectors for all our models.

For our other model formulations, we make the minimal number of changes to this basic framework. In the specific factors model we have three factors: capital, skilled and unskilled labour, though capital is sector-specific. In the other two versions (Heckscher-Ohlin or $\mathrm{H}-\mathrm{O}$, and partial mobility) we reallocate capital income from our database to the other two factors proportionately by sector, so the simplified model just has two factors. The H-O model differs from 
the partial mobility one in that $\lambda_{u}$ and $\lambda_{s}$ are set to zero: calibration based on this assumption means assuming a long-run equilibrium in the economy (ie the standard H-O model), whereas with $\lambda_{u}$ set at a non-zero level we are assuming the economy is at a short-run equilibrium only. This latter treatment means that the adjustment process for the unskilled factor reflects an outcome influenced by short-run adjustment costs.

In all three models calibrated here, both goods are fully tradable and perfect substitutes for foreign goods. Consequently, if we assume the UK is a small, open economy, prices of the two goods are determined on global markets and can be taken as exogenous (although there is a downward shift in the price of the unskilled-intensive good over time, reflecting the opening up of new supply sources in Asia and elsewhere). A consequence of these assumptions is that the production and factor demand side of the economy can be treated as separable from the goods demand side: we can simply treat World prices as given, with no need to model domestic goods demand, import and export volumes.

One potential problem with the above trade formulations (indeed with all neoclassical trade models) is the difficulty of reconciling the model with observed two-way trade. This is frequently used as a justification for the use of new trade theory models based upon a 'love of variety' approach. However, while we acknowledge the importance of two-way trade between advanced countries in the skill-intensive sectors, arguably trade between the rich countries and the developing World is driven more by specialization, with the rich countries as a group exporting skill-intensive goods and services and importing less skill- 
intensive goods. In this context, it may well be appropriate to use more factordriven models of trade, such as in this paper. ${ }^{11}$ Consequently, we have used data for net imports/exports in this model.

To calibrate either the $\mathrm{H}-\mathrm{O}$ or partial mobility models to the start- and endyears, we solve the model for parameter values given data for the two years, 1979 and 1995 with prices, wages, output and employment set at their observed values. We assume a value for the elasticity of substitution between factors in production $\sigma$ (we assume the same elasticity for both sectors, to rule out the possibility of factor intensity reversals), and we assume values for the differential between skilled and unskilled wages in the expanding and declining sectors $E$ and $M$.

Note that, for our central case we assume an elasticity of substitution between factors in production, $\sigma=1.25$. In Appendix 2, we investigate sensitivity cases where $\sigma=0.5$ and $\sigma=2$. The unknowns at this stage are the model parameters for each sector and each time period $\left(\alpha_{\text {uit }}, \alpha_{s i t}, \beta_{i t}\right.$ and $\left.A_{i t}\right)$.

\subsection{Data}

We use data for the UK for 1979 and 1995 for our model analyses, similar to those used by Abrego and Whalley (1999b). They used data on skilled and unskilled employment and wages for two broad categories of industry, taken from the UK Labour Force Survey. ${ }^{12}$

\footnotetext{
${ }^{11}$ Note that Abrego and Whalley (1999a) investigate the effects of introducing differentiated goods into general equilibrium trade-wages decompositions (a simple form of Armington model). In this paper, we prefer to investigate the effects of factor immobility separately from those of product differentiation.

${ }^{12}$ Our aggregate unskilled-intensive sector consists of: 1 . agriculture, forestry and fishing, 2 . food, drink and tobacco, 3. textiles, apparel and leather, 4. timber, furniture, etc., 5. rubber
} 
Data on aggregated traded prices is not easy to come by: we use an estimate

of a 7.9 per cent fall in the relative price of unskilled-intensive imports between 1979 and 1995 based on an estimate for the same aggregate sectors as above, derived by Abrego and Whalley (1999) from Neven and Wyplosz (1999). ${ }^{13}$

As two of our models have only two factors, against the three in Abrego and Whalley (1999a), we reallocate income accruing to the fixed factor in each sector between skilled and unskilled labour in the proportions used in that sector. Following Abrego and Whalley value added is rounded to equal gross output. Again, this is done to keep the model as close as possible to the schematic formulation of the Heckscher-Ohlin-Samuelson theory, which does not take account of intermediate inputs.

A summary version of the 1979 and 1995 UK data we use is shown in Table 1 below. Price and wage data are in real terms. An important feature of the data used is the marked difference in skilled/unskilled labour usage between the two sectors: the ratio of skilled to unskilled workers is more than twice as great in sector $E$ as in sector $M$ in both years.

The rise in the average real wage of unskilled labour was approximately

and plastic, 6. bricks, pottery, glass, cement, etc., 7. metal manufacture, 8. metal goods not elsewhere specified, 9. construction, transport and communication, 10. distributive trade and miscellaneous services. All other sectors are aggregated into the skill-intensive sector: 1 . mining and quarrying, 2. paper, printing and publishing, 3. coal and petroleum products, 4. chemical and allied industries, 5. mechanical engeneering, 6. shipbuilding and maritime engeneering, 7. vehicles, 8. instrument engineering, 9. electrical engeneering, 10. professional and scientific services, 11. gas, electricity and water, 12. insurance, banking, finance and business services, 13. public administration.

${ }^{13}$ Although Neven and Wyplosz (1999) find that prices of imports from OECD countries or from developing countries do not vary much by sector skill-intensity, imports from developing countries fall relatively in price to those from OECD countries, and these weigh more heavily in total UK imports in the skill-intensive sectors. 
23 per cent between 1979 and $1995,{ }^{14}$ reflecting an increase in the premium for skilled over unskilled wage rates from $22 \%$ in 1979 to over $59 \%$ in 1995 . This occurs despite the ratio of skilled/unskilled labour inputs rising in both sectors. While there is an increase in the share of skilled intensive exportables in total production, both sectors show rising output. The change in industrial structure in the data is therefore a relatively minor factor compared with what a Heckscher-Ohlin model would usually be expected to produce in response to the assumed $7.9 \%$ fall in the relative goods prices. ${ }^{15}$

\footnotetext{
${ }^{14}$ This is calibrated to UK GNP growth - see the UK national accounts 1996 Table 1.3.

${ }^{15} \mathrm{~W}$ ith an elasticity of substitution of 1.25 between the two fully-mobile factors, and starting with output and employment as in our database for 1979, we show complete specialisation in good $X$ after a price fall of just $6.3 \%$ in good $M$. This corresponds to a change of nearly $40 \%$ in relative skilled wages. Details of this calculation are available on request from the authors.
} 
Table 1: 1979 and 1995 UK data used in calibrating short-run models

\begin{tabular}{|c|c|c|c|c|}
\hline & & & 1979 & 1995 \\
\hline \multirow[t]{11}{*}{ Labour Input (bn hrs) } & Good M & Unskilled & 36.0 & 26.4 \\
\hline & & Skilled & 19.0 & 25.2 \\
\hline & & Total & 55.0 & 51.6 \\
\hline & & $S / U$ & 0.5 & 1.0 \\
\hline & Good E & Unskilled & 24.3 & 16.5 \\
\hline & & Skilled & 33.4 & 34.8 \\
\hline & & Total & 57.7 & 51.4 \\
\hline & & $S / U$ & 1.4 & 2.1 \\
\hline & Total & Unskilled & 60.3 & 42.9 \\
\hline & & Skilled & 52.4 & 60.1 \\
\hline & & Total & 112.7 & 103.0 \\
\hline Hourly wage pounds & Average & Unskilled & 5.47 & 6.45 \\
\hline 1995 prices & & Skilled & 6.67 & 10.23 \\
\hline Average wage ratio & & & 1.22 & 1.59 \\
\hline \multirow[t]{2}{*}{ Output index } & Good M & & 100.0 & 134.0 \\
\hline & Good E & & 100.0 & 138.1 \\
\hline \multirow[t]{2}{*}{ Goods prices } & Good M & & 1 & 0.921 \\
\hline & Good E & & 1 & 1 \\
\hline Good M \% of total value added & & & $47.5 \%$ & $44.7 \%$ \\
\hline
\end{tabular}


The unskilled labour mobility cost, $\lambda_{u}$, reflects studies which tend to indicate that unskilled labour may be less mobile between sectors than skilled. Kruse (1988) suggests unemployment periods in the US are generally longer for unskilled rather than skilled workers, which, in terms of our model, might suggest a higher threshold wage differential for the unskilled before they start to move between sectors. This is borne out by Haynes, Upward and Wright's (2000) UK study, which suggest that those with lower skills experience longer unemployment duration.

We have chosen, for simplicity, to assume that only unskilled labour, factor $U$, is affected by mobility costs (ie $\lambda_{s}=0 ; \lambda_{u} \geq 0$ ) and we use a figure of 13.7 $\%$ for $1995,{ }^{16}$ an 'upper end' estimate of mobility costs. In later sensitivity analysis, we also evaluate models with lower values.

\section{MODEL RESULTS}

We use three calibrations to the 1979 and 1995 data: one involving the longrun two-factor model in which all factors are able to move freely in response to price and technology shocks; a second short-run model in which unskilled labour is only partially mobile, if intersectoral wage differentials exceed a threshold, assumed to be $13.7 \%$ of wages; and a third using a three-factor model with sectorally fixed capital. We concentrate initially on the case where the elasticity of substitution between factors of production is 1.25 in both sectors.

\footnotetext{
${ }^{16}$ This assumes that the $7 \frac{3}{4} \%$ difference in wages between sectors reported by Greenaway et al. (2001) for the UK in 1990 is explained entirely by lower unskilled wages in the declining sectors, in turn reflecting an unwillingness to move due to mobility costs. We assume the 7 $\frac{3}{4} \%$ difference in average wages comprises no differential for skilled workers and a $13.7 \%$ differential for unskilled.
} 


\subsection{Components of the decomposition}

The model laid out in Section 3 uses a relatively flexible functional form, compared to standard general equilibrium models, with several component parameters, each of which is calibrated to the data for 1979 and 1995. Consequently, we are able to decompose the observed change in wage inequality between 1979 and 1995 between the effects of changing each of a number of sets of parameters. With reference to the production function in equation (3) in particular, these are:

a) World prices: the change in $P_{E} / P_{M}$.

b) Sector-biased technology: the relative changes in $A_{E}$ and $A_{M}$.

c) Skill-biased techological progress: the shift in the sectoral share parameters, $\beta_{E}$ and $\beta_{M}$.

d) Factor quality: changes in $\alpha_{U}$ and $\alpha_{S}{ }^{17}$

e) Factor endowments: changes in $\bar{U}$ and $\bar{S}$.

\subsection{Results tables}

Table 2 outlines our decomposition results for observed changes in relative wages of skilled and unskilled labour between 1979 and 1995 using these three calibrated models. The contribution of various causal factors to the observed change in the average skilled to unskilled wage ratio, which Table 1 indicates increased from 1.22 to 1.59 , is expressed by the contribution of each causal factor

\footnotetext{
${ }^{17}$ We are using a somewhat more sophisticated breakdown of technology than much of the literature, since we include overall factor quality changes as a possible cause of distributional changes. On the definitions used, for example, in Haskel and Slaughter (2002), factor quality changes will also have some sector-biased effects (since a relative rise in the quality of skilled labour will make the skill-intensive industry more competitive).
} 
as a percentage of the total change.

Table 2: Model decomposition of wage inequality

\begin{tabular}{|llll||}
\hline \hline $\begin{array}{l}\text { Central case changes } \\
\text { Component factors: }\end{array}$ & factors mobile & adjustment cost & Factor \\
\hline World price change & $152 \%$ & $83 \%$ & $19 \%$ \\
\hline Technology: & & & \\
-sector bias & $-491 \%$ & $-228 \%$ & $-43 \%$ \\
-skill bias & $184 \%$ & $187 \%$ & $256 \%$ \\
-capital bias & $0 \%$ & $0 \%$ & $-8 \%$ \\
-factor quality & $255 \%$ & $151 \%$ & $67 \%$ \\
\hline & & & $-191 \%$ \\
Endowments & $0 \%$ & $-92 \%$ & $100 \%$ \\
\hline
\end{tabular}

In the long-run Heckscher-Ohlin factors mobile model (first column of numbers), the increase in skilled and fall in unskilled factor endowments has no effect, as the factor price insensitivity result (see, e.g. Leamer and Levinsohn (1995)) suggests. However, the model shows substantial sensitivity to the change in world prices, which alone accounts for $152 \%$ of the total observed wage change. There is also substantial factor bias in favour of the skilled factor (skill bias $+184 \%$ and factor quality $+255 \%$ ), and rise in the skilled share of output. These results fit the observed wage and output changes due to a sizeable sector-biased technical change in the opposite direction $(-491 \%)$, favouring the 
unskilled intensive sector $M$.

In the second column, the partial mobility model shows different results. The change of endowments has a large effect on relative wages narrowing the gap between skilled and unskilled wage rates $(-92 \%$ of the total net observed change). The effect of world prices is reduced to around $83 \%$ of the observed total wage change, while sector bias, which still favours the unskilled-intensive good, is also smaller in this model compared to the factors mobile model $(-228 \%$ of the observed change against $-491 \%)$. The main factor in this model behind the increased inequality is the change in the skill share within industries $(187 \%$ of the observed change), with a slightly smaller contribution from factor quality.

The final column of Table 2 reports results for the specific factor model. Sectoral output and employment are less sensitive to price or sector-biased technical changes in this case. World price changes account for just $19 \%$ of the total observed change in relative wages, $1 / 10$ of the change in the HeckscherOhlin model. Sector-biased technical change has a moderate damping effect on inequality $(-43 \%)$. The main picture conveyed by this model is strong factorbiased change within industries $(+256 \%$ of the observed net change) in favor of skilled labour, offset partially by large effects of endowment changes (-191\%).

Table 3a: Sensitivity of decomposition in short run models to key parameters 


\begin{tabular}{|c|c|c|c|c|}
\hline $\begin{array}{l}\text { Per cent of total change } \\
\text { in ratio of skilled } \\
\text { / unskilled earnings }\end{array}$ & Long-run model & $\begin{array}{l}\text { Short run } \\
\text { adj cost } 5 \%\end{array}$ & $10 \%$ & $14 \%$ \\
\hline World Price Change & $152 \%$ & $126 \%$ & $99 \%$ & $83 \%$ \\
\hline \multicolumn{5}{|l|}{ Technology bias: } \\
\hline -sector bias & $-491 \%$ & $-387 \%$ & $-288 \%$ & $-228 \%$ \\
\hline -skill bias & $184 \%$ & $186 \%$ & $186 \%$ & $187 \%$ \\
\hline -capital bias & $0 \%$ & $0 \%$ & $0 \%$ & $0 \%$ \\
\hline -factor quality & $255 \%$ & $212 \%$ & $173 \%$ & $151 \%$ \\
\hline Endowments change & $0 \%$ & $-37 \%$ & $-70 \%$ & $-92 \%$ \\
\hline Total & $100 \%$ & $100 \%$ & $100 \%$ & $100 \%$ \\
\hline
\end{tabular}

Table $3 a$ reports the sensitivity results for the partial mobility model to changes in the assumed mobility cost. Moving rightward the columns show adjustment costs for labour increasing from zero (Long-run model) to our maximum $13.7 \%$, and shows that the effect of trade upon wage changes falls markedly as the adjustment cost rises, from $152 \%$ of total observed changes in the Heckscher-Ohlin case to $83 \%$ in our maximum adjustment cost case (in other words, nearly halved). The latter is still, however, somewhat larger than estimated by most other empirical studies of the contribution of trade. The roles of factor-biased technology changes, in the opposite direction: the role of endowment changes rises rapidly as factor mobility costs are introduced. 
Table 3b: Sensitivity of decomposition in short run models to key parameters

\begin{tabular}{|c|c|c|c|c|c|c|}
\hline $\begin{array}{l}\text { Per cent } \\
\text { of total change } \\
\text { in ratio of skilled } \\
\text { / unskilled earnings }\end{array}$ & Long-run & $\begin{array}{l}\text { Specific factor } \\
\text { share } 2 \%\end{array}$ & $5 \%$ & $10 \%$ & $20 \%$ & $30 \%$ \\
\hline World Price Change & $152 \%$ & $101 \%$ & $65 \%$ & $41 \%$ & $24 \%$ & $17 \%$ \\
\hline \multicolumn{7}{|l|}{ Technology bias: } \\
\hline -sector bias & $-491 \%$ & $-324 \%$ & $-201 \%$ & $-119 \%$ & $-60 \%$ & $-36 \%$ \\
\hline -skill bias & $184 \%$ & $204 \%$ & $207 \%$ & $210 \%$ & $213 \%$ & $214 \%$ \\
\hline -capital bias & $0 \%$ & $0 \%$ & $0 \%$ & $0 \%$ & $0 \%$ & $0 \%$ \\
\hline -factor quality & $255 \%$ & $188 \%$ & $137 \%$ & $102 \%$ & $77 \%$ & $66 \%$ \\
\hline Endowments change & $0 \%$ & $-70 \%$ & $-108 \%$ & $-134 \%$ & $-153 \%$ & $-161 \%$ \\
\hline Total & $100 \%$ & $100 \%$ & $100 \%$ & $100 \%$ & $100 \%$ & $100 \%$ \\
\hline
\end{tabular}

Table $3 b$ summarises the sensitivity of the specific factor model to different assumptions about the share of fixed factors in value added. The higher the assumed share of fixed factors in value added, the less role for trade or sector bias and the greater the role of endowment changes. However, the most revealing columns are those where we have assumed just $2 \%$ or $5 \%$ of value added consists of fixed factor payments. Introducing relatively small amounts of these fixed factors modifies the behaviour of the model quite rapidly compared to to the Heckscher-Ohlin model: the effect of traded prices, for example, is cut from 
$152 \%$ of observed changes to $101 \%$ with $2 \%$ of factors fixed, and $65 \%$ with a $5 \%$

fixed factor share. ${ }^{18}$

The tables in Appendix 2 explore the sensitivity of our decomposition results in the three models to the elasticity of substitution between unskilled and skilled labour in production, which we set at 0.5 and 2 instead of our central case value of 1.25 .

Comparing estimates of the contribution of various factors when the assumed elasticity of substitution between skilled and unskilled labour is changed shows that the relationship between elasticity and decomposition estimates is neither simple nor monotonic. In most cases the effects of skill bias (positive) and endowments change (negative) on relative wages are higher when the elasticity of substitution between factors is lower. Factor quality is more important in explaining relative wage changes with higher substitution elasticities. The relationship to price changes and sector bias seems to be non-monotonic.

\footnotetext{
${ }^{18}$ The result that the presence of a fixed factor alters the effect of trade upon factor returns is, of course, not new. However, the quantitative assessment of the degree of effect of small amounts of a fixed factor upon the response of factor returns to traded goods prices has not been shown before.
} 


\section{SUMMARY AND CONCLUSIONS}

In this paper, we compare the use of short-run and long-run trade models to decompose changes in observed wage inequalities between skilled and unskilled labour over the period 1979-95 for the UK into trade and technology, and endowment change components. Results of these decompositions are very different depending upon whether a short-run model, with limited mobility of unskilled labour, or a long-run model is used to explain the observed changes. This emphasises that different assumed model structures applied to the same data in decomposition will substantially affect the perception of the role of trade in explaining wage inequality changes. Since factors are generally believed to be more mobile in the long-run than the short-run, the time scale over which the decomposition is being carried out is also important.

In the long-run model, the factor-bias of technical change has no effect (except insofar as the relative quality of skilled labour has risen). As theory would suggest, note that factor endowments have no effect in the long run. In contrast, the effects of observed world price increases are very large: on its own these price increases would cause larger shifts in output towards the skill-intensive goods, and larger rises in skill premia than actually observed. The long-run model can only be made consistent with the observed output and income changes if the sector-bias of technical change (the residual category of the decomposition) is in the opposite direction: for UK total factor productivity in the unskilledintensive sector to have risen faster than in the skill-intensive sector, so damping the tendency of output to switch. 
By contrast, when we use a short-run model for these decompositions, one in which unskilled labour is only partially mobile, the decomposition results are quite different. The rise in the relative supply of unskilled labour now has a sizeable damping effect on inequality. Factor-biased technical change (leading to a rise in skilled/unskilled input ratios in both sectors) despite rising skill premia will raise relative skilled wages in a short-run model. The effect of trade is less marked in the short-run model, though still quite substantial. The sector-bias in technical progress (which had been large and favoured the unskilled-intensive sector in the long-run model) is relatively minor in our short-run model.

The other short-run model specification we examine is a specific factor model, where capital is assumed to be sector-specific. The effects of this are even more marked than in the partial mobility case - prices and sector-biased technical change have only a small effect, while factor-biased change is the main cause of insensitivity in inequality, offset by endowment changes. Sensitivity analysis shows that, even when only a small proportion of valued added is linked to fixed factors; behaviour of the model can be noticeably changed compared to the Heckscher-Ohlin formulation.

The prima facie conclusion of this work (in common with the various papers by Abrego and Whalley ((1999a), (1999b) and 2000)) is that decomposition of inequality changes on the basis of aggregate data from a single country is probably a spurious exercise, since the aggregate data on prices, wages, output, employment and net trade are consistent with a whole variety of different decompositions, depending, inter alia, on how mobile labour and capital are 
assumed to be between sectors.

However, while this may seem a pessimistic conclusion, we should add that there are plenty of alternative micro-level studies which should assist in narrowing down the range of possible model specifications: these include studies of capital fixity and the dynamics of investment at industry level and of labour matching processes. In addition, there are at least some data available on relative sector bias of computerization: Haskel and Slaughter's (2002) paper is invaluable in this regard, in that it suggests that technical progress has been faster in skill-intensive sectors - a result which is inconsistent with the full factor mobility models summarized in section 5 , which had implied relatively faster technical progress in unskilled-intensive sectors (Table 2). This should be seen as indicating that a relatively short-term model is probably more plausible.

Cross-country data may also be of value in selecting models, in the sense that we would probably consider models which require vast differences in technical progress across OECD countries to be implausible. Nevertheless, factor fixity may vary across countries: for example, different factor hiring and firing rules and industrial subsidies may have slowed the response in some European countries to falling global prices for unskilled-intensive manufactures ${ }^{19}$ compared to $^{2}$ the USA or United Kingdom (so that the smaller inequality changes in the former reflects a 'short-run' response which has been prolonged by policy).

If a relatively short-run model is seen as the more plausible, then this has a number of implications. First, changes in factor endowments should not be

\footnotetext{
${ }^{19}$ See Bentolila and Bertola (1990).
} 
ruled out as a causal factor (mostly serving to damp observed changes), and the role of skills training in reducing inequality in the short- to medium-run should not be ignored. Secondly, Stolper-Samuelson mandated wage equations may not necessarily be preferable in the short run for analysing labour demand changes compared to the output-driven labour demand models (eg Borjas et al., 1992; Murphy and Welch, 1991; and Katz and Murphy, 1992). ${ }^{20}$ Finally, if observed inequality changes to date, particularly in Continental Europe, reflect only a relatively short-run response to changes in global prices and technology, then we should be prepared for ongoing pressure on unskilled wages for some time to come.

\section{References}

[1] Abrego, L. and J. Whalley (1999a): 'Decomposing wage inequality using general equilibrium models', NBER Working Paper no 7312, August 1999.

[2] Abrego, L.E. and Whalley, J. (1999b), 'The form of technical progress in the trade and wages debate.' Mimeo CSGR,:University of Warwick.

[3] Abrego, L.E. and Whalley. J, (2000): 'The choice of structural model in trade/wage decompositions.' Review of International Economics 9, 3 (August).

\footnotetext{
${ }^{20}$ It is worth noting that Deardorff (2000) concludes tentatively that the factor content of trade is useful in analysing the effects of trade on wages, as long as it is used with care. Our paper goes somewhat further in casting doubt on the short-run viability of the alternative, mandated wages approach.
} 
[4] Anderton, R. and P.Brenton (1999): 'Outsourcing and low-skilled workers in the UK.' Bulletin of Economic Research, 51, 4, (Oct 1999) 267-85.

[5] Baxter, Marianne (1992): 'Fiscal policy, specialization, and trade in the two-sector model: the return of Ricardo?' Journal of Political Economy 100, 4. (August), 713-744.

[6] Bentolila, S. and G.Bertola (1990): 'Firing costs and labour demand: how bad is Eurosclerosis?', Review of Economic Studies 57, 3, 381-402.

[7] Berman, E., J.Bound and Z.Griliches (1994): 'Changes in the demand for skilled labour within U.S. manufacturing: evidence from the annual survey of manufactures', Quarterly Journal of Economics 109, 367-397.

[8] Berman, E., J.Bound and S.Machin (1998): 'Implications of skill-biased technological change: international evidence', Quarterly Journal of Economics 113, 1245-1280.

[9] Bhagwati, J. (1997): 'Trade and wages: a malign relationship.' In Kuyvenhown, A.,Memedovic, O. and Molle,W. (eds), 'Globalization of Labour Markets'. Kluwer: Dordrecht, pp.31-65.

[10] Borjas,G., R.Freeman and L.Katz (1992): 'On the labour market effectsof immigration and trade', in Borjas,G.and R.Freeman, (eds) Immigration and the Work Force: NBER, 213-44. Cambridge,MA. 
[11] Bound, J. and Johsnon, G. (1992): 'Changes in the structure of wages in the 1980s: An evaluation of alternative explanations', American Economic Review 82, 371-392.

[12] Clarete, R.L, Trela, I. and Whalley, J.(1991): 'Equilibrium with quasi-fixed factors' (University of Western Ontario, in mimeo).

[13] Deardorff, A. (2000): 'Factor prices and the factor content of trade revisited: what's the use?' Journal of International Economics 50(1), 73-90.

[14] Deardorff, A. and R.W.Staiger (1988): 'An interpretation of the factor content of trade.' Journal of International Economics 24, 93-107.

[15] Freeman, R.B. (1995): 'Are your wages set in Beijing?‘ Journal of Economic Perspectives, 9(3), 15-32.

[16] Greenaway, D. , Upward, R. and Wright, P. (2001): 'Sectoral mobility in UK labour markets.' Oxford Review of Economic Policy, 16(3), 57-75.

[17] J.E. Haskel and M.J.Slaughter (1998): 'Does the sector bias of skill-biased technical change explain changing skill premia ?' European Economic Review $46,1757-1783$.

[18] Haynes, M., R.Upward and P.Wright (2000): 'Smooth and sticky adjustment: a comparative analysis of the US and UK.' Review of International Economics 8, 517-32.

[19] Johnson, H.G. (1966): 'Factor market distortions and the shape of the transformation frontier.' Econometrica 34, 686-98. 
[20] Jones, Ronald W. (1971): 'A three-factor model in theory, trade, and history', in Bhagwati, J. et al., eds., Trade, Balance of Payments, and Growth: Essays in Honor of C. P. Kindleberger, Amsterdam: North-Holland.

[21] Katz, L.F. and K.M. Murphy (1992): 'Changes in relative wages, 19631987: supply and demand factors.' Quarterly Journal of Economics 35.78.

[22] Kose, M.Ayhan and R.Riezman (2000): 'Understanding the welfare effects of preferential trade agreements.' Review of International Economics, 8, 4, (November) 619-633(15)

[23] Krugman, P.R.(1995): 'Technology, trade and factor prices.' NBER Working Paper 5355, Cambridge, MA.

[24] Kruse, D.L. (1988): 'International trade and the labor market experience of displaced workers.' Industrial and Labor Relations Review 41 (April) 407.

[25] Leamer, E.E. (1998): 'In search of Stolper-Samuelson linkages between international trade and lower wages.' In Susan Collins (ed) Exports, Imports and the American Worker. Washington D.C.: Brookings Institution.

[26] Leamer, E.E. (2000): 'What's the use of factor contents?' Journal of International Economics, 50(1), 17-49.

[27] Leamer, E.E., and Levinsohn, J. (1995), 'International trade theory: the evidence.' In Gene M. Grossman and Kenneth Rogoff (eds) Handbook of International Economics, Vol. 3. Amsterdam: North Holland, pp 13381394. 
[28] Mayer, W. (1974): 'Short-run and long-run equilibrium for a small open economy.' Journal of Political Economy, 82, 5, 955-967.

[29] Melvin, J.R. (1971): 'On the derivation of the production possibility curve', Economica, 38, 151, 287-94.

[30] Murphy, K. and F. Welch (1989), 'Wage premiums for college graduates: recent growth and possible explanations.' Educational Researcher 18, 1726.

[31] Mussa, M. (1974): 'Tariffs and the distribution of income: the importance of factor specificity, subsitutability and intensity in the short and long run.' Journal of Political Economy 82, 1191-204.

[32] Neary, J.P. (1978): 'Short-run capital specificity and the pure theory of international trade.' Economic Journal 88, 351, 488-510.

[33] Neven, D. and Wyplosz, C. (1996): 'Relative prices, trade and restructuring in European industry.' CEPR Discussion Paper No 1451.

[34] Slaughter, M, (1999): 'Globalisation and wages: a tale of two perspectives.' Research paper 99/5, Centre for Research on Globalisation and Labour Markets, University of Nottingham.

[35] Stolper, W. and P. Samuelson (1941): 'Protection and real wages.' Review of Economic Studies 9, 58-73.

[36] Wood, A. (1994): 'North-South Trade, Employment and Inequality.' Oxford: Clarendon Press.Mass. 


\section{Appendix 1: Elasticity sensitivity of model}

\section{based decompositions}

Table A1: Elasticity sensitivity of model based decompositions - substitution

elasticity between skilled and unskilled set at 0.5

\begin{tabular}{||lllcc||}
\hline \hline & & Factors mobile & SR & Specific \\
& & LR & adj cost & factor \\
\hline World price change & (trade) & $86 \%$ & $41 \%$ & $34 \%$ \\
\hline Technology & Sector bias & $-330 \%$ & $-137 \%$ & $-106 \%$ \\
& Skill bias & $310 \%$ & $315 \%$ & $631 \%$ \\
& capital bias & $0 \%$ & $0 \%$ & $0 \%$ \\
& factor quality & $54 \%$ & $-6 \%$ & $-83 \%$ \\
\hline Endowments & & $0 \%$ & $-113 \%$ & $-369 \%$ \\
\hline TOTAL & & $100 \%$ & $100 \%$ & $100 \%$ \\
\hline \hline
\end{tabular}


Table A.2: Elasticity sensitivity of model based decompositions - substitution

elasticity between skilled and unskilled set at 1.25

\begin{tabular}{||lcccc||}
\hline \hline & & Factors mobile LR & SR adj cost & Specific factor \\
\hline World price change & (trade) & $152 \%$ & $83 \%$ & $19 \%$ \\
\hline Technology & Sector bias & $-491 \%$ & $-228 \%$ & $-43 \%$ \\
& Skill bias & $184 \%$ & $187 \%$ & $256 \%$ \\
& capital bias & $0 \%$ & $0 \%$ & $0 \%$ \\
& factor quality & $255 \%$ & $151 \%$ & $67 \%$ \\
\hline Endowments & & $0 \%$ & $-92 \%$ & $-191 \%$ \\
\hline TOTAL & & $100 \%$ & $100 \%$ & $100 \%$ \\
\hline \hline
\end{tabular}


Table A.3: Elasticity sensitivity of model based decompositions - substitution elasticity between skilled and unskilled set at 2

\begin{tabular}{||lcccc||}
\hline \hline & & Factors mobile & SR adj cost & Specific \\
& & LR & adj cost & factor \\
\hline World price change & (trade) & $155 \%$ & $67 \%$ & $12 \%$ \\
\hline Technology & Sector bias & $-400 \%$ & $-132 \%$ & $-22 \%$ \\
& Skill bias & $42 \%$ & $19 \%$ & $64 \%$ \\
& capital bias & $0 \%$ & $0 \%$ & $0 \%$ \\
\hline factor quality & $303 \%$ & $221 \%$ & $171 \%$ \\
\hline TOTAL & & $0 \%$ & $-75 \%$ & $-120 \%$ \\
\hline \hline
\end{tabular}




\section{Appendix 2: The calibration procedure}

We use the eight first-order conditions for cost-minimising behaviour (equations for 2 factors for 2 sectors for 2 years, (1979 and 1995)).

$$
\begin{aligned}
W_{u i t} & =P_{t i} A_{i t}\left(Y_{i t} / A_{i t} U_{i t}\right)^{1 / \sigma} \beta_{i t} \alpha_{u i t}^{(\sigma-1) / \sigma} \\
W_{s t} & =P_{i t} A_{i t}\left(Y_{i t} / A_{i t} S_{i t}\right)^{1 / \sigma}\left(1-\beta_{i t}\right) \alpha_{s i t}^{(\sigma-1) / \sigma}
\end{aligned}
$$

We assume a value for the elasticity of substitution between factors in production, which we also assume to be constant across sectors (we carry out the calibration and simulations for a central case $\sigma=1.25$ with sensitivity values of $\sigma=0.5$ and $\sigma=2.0$ ). Using this, it is possible to calibrate the model, i.e. to generate values of the technical coefficients $\left(\alpha_{u}, \alpha_{s}, \beta\right.$, and $\left.A\right)$ for each sector. The other constraint we assume is that there is no decline in industry-specific technology in either sector (ie $A_{i}$ cannot decline from period 0 to period 1 ), based on the assumptions that technological innovations will not be unlearnt once developed.

For the specific factor model, we calibrate capital share coefficients $\gamma_{i}$ from income shares. The calibrated values of the unskilled share parameters, $\beta_{i}$,

and the labour quality coefficients, $\alpha_{u i}$ and $\alpha_{s i}$ are unchanged compared to the calibrated $\mathrm{H}-\mathrm{O}$ model, while the $A_{i}$ scale parameters for labour income are smaller.

Having determined parameter values in each of the models using the cali- 
bration procedures described above (which we use for the long-run model where $\lambda_{u}, \lambda_{s}=0$ and the short-run model where $\lambda_{u}>0$ ), we then compute counterfactual equilibria with each model. Using the 1979 UK price, technology and endowment data as inputs, we compute equilibria for the UK economy if endowments, prices and/or technological parameters are separately changed to their 1995 model values. We then compare these computed model equilibria to the actual 1995 data in which all these changes jointly appear.

Previous studies (e.g. Abrego and Whalley (2000)) have decomposed the causes of increased inequality by carrying out simulations, first altering prices, then technological parameters (or vice-versa). Due to model nonlinearities, the order of decomposition can make a difference to how much change is attributed to which cause. For this reason, we follow a method (similar to that in Kose and Riezman's (2000) study of customs unions), in which endowments, trade and technology are changed in a series of small steps (first 1/10 of the total change in endowments, then $1 / 10$ of the total change in prices and $1 / 10$ of the total change in technology, then repeating the cycle): the smaller the steps, the less the order matters. ${ }^{21}$

\footnotetext{
${ }^{21}$ This was confirmed by carrying out decompositions in different orders with progressively smaller steps. As the steps grow smaller, the decompositions converge.
} 